\title{
РЕГИОНААЬНЫЕ КОНФАИКТЫ
}

\author{
Хабенская Е. О.
}

\section{ОТНОШЕНИЯ СЕНЕГААА С РЕСПУБАИКОЙ ГАМБИЯ: ОПЫТ И ПЕРСПЕКТИВЫ}

\begin{abstract}
Аннотащия. Отношения Сенегала с бывщей британской колонией Республикой Гамбия (РГ) всегда носили особый, зачастую драматический характер. Особое внимание каждого из четырех сенегальских президентов к укреплению отношений с этой страной - самоймаленькой в континентальной Африке - определялось географическим положением Гамбии, расположенной внутри сенегальской территории. Это небольшое государство узкой полосой от Атлантики - на восток на несколько десятков километров - «врезается» в самый центр территории Сенегала, отделяя его южную область - Казаманс от северной части страны. Методологическую основу исследования составляют системный, структурно-функииональный, сравнительно-исторический, сравнительно-политический, геополитический и культурно-цивилизационньй подходы, методы анализа, синтеза, индукции, дедукиии, моделирования, наблюдения. На границе Сенегала и Гамбии численно доминируют родоплеменные группы диола. Именно это население в наибольщей степени оказалось втлнуто в затлжной конфликт в южной области Сенегала - Казамансе. Этот регион уже более тридиати ет является «горячей точкой», одним из центров политической нестабильности в Западной Африке, очагом затлжного внутригосударственного конфликта. С 1982 г.здесь действует Авижение демократических сил Казаманса (ААСК) - политическая организация, наиболее радикальные сторонники которой требуют отделения этой территории от Сенегала и создания независимого государства. ААСК находит широкую поддержку среди населения региона, особенно среди диола.
\end{abstract}

Ключевые слова: международные отношения, конфликтология, Африка, Гамбия, Сенегал, дипломатия, политика, конфликты, интересы, безопасность.

B Гамбии, как и в Сенегаме, подавмяющая часть населения, во всяком случае, формально, исповедует ислам - около $90 \%$. Социокумьтурный состав насемения Авух стран очень близок, отмичия мишь в численности тех ими иных групп. Всего в Сенегаме насчитыва- ют более 20 размичных этнолингвистических и родоплеменных групп, самая многочисленная из которых - волоф включает 43\% населения. Группы фульбе (пумаар) составмяют $24 \%$ насемения Сенегала, серер - $15 \%$, Аиола - 4\%, манАинго (малинке) - $3 \%$, сонинке - $1 \%$. ОАин 
процент прихоАится на европейцев и ииванцев, 9\% - на другие мемкие группы ${ }^{1}$. Самые многочисленные родоп еменные группы Гамбии это мандинго (42\%), фумьбе (18\%), волоф (16\%), Аиола (10\%) и сонинке (сараколе - 9\%) 2 .

Аеятельность радикамьных боевых групп ААСК в Казамансе и на границе с Гамбией всегАа оказыва а бомьшое вмияние на отношения Авух сосеАних стран. Из особенностей географического расположенияГамбиивытекаютпроблемы теснейших контактов родственного насемения на полупрозрачной границе, свободного перемещения сепаратистов и оружия и невозможности обеспечить безопасность без участия руководства сосеАней страны (Сенегама). Конечно, территория северного Казаманса быма значительно меньше задействована в конфиикте, чем его южная часть, граничащая с Гвинеей-Бисау. ОАнако в отАемьные периоды зАесь также имела место активная Аеятельность повстанческих групп ААСК, в том числе «минная война», провоАи$\Lambda$ ись военные операции и «зачистки» сенега $\mathbf{\text { b- }}$ ской армии, что влекмо за собой массовый исхоА населения Казаманса на территорию Гамбии.

Сложности в выстраивании гармоничныхдобрососеАских отношений, тесных политических и экономических связей межАу Авумя странами, к которым так стремимось руководство Сенегала (из-за анклавного положения своей южной области), были связаны и с иАеологическими противоречиями их режимов. Если политические милеры Сенегала всегАа ориентировались на ценности запаАной демократии, то руководство Гамбии, особенно с начала 2000-х гг, планомерно уничтожало Аемократические институты в этой стране. Тем не менее, на раннем этапе постколониацьного развитиявисториивзаимоотношенийдвухстран была попытка объеАинения в рамках конфедерации.

\section{ГАМБИЯ ПОСАЕ НЕЗАВИСИМОСТИ. КОНФЕАЕРАЦИЯ СЕНЕГАМБИЯ}

Гамбия Аобимась независимости от Великобритании в февраме 1965 г., и в течение пяти

\footnotetext{
${ }^{1}$ The World Factbook - Senegal // Central Intelligence Agency (https://www.cia.gov/library/publications/theworld-factbook/geos/sg.html)

${ }^{2}$ The World Factbook - Gambia // Central Intelligence Agency (https://www.cia.gov/library/publications/theworld-factbook/geos/ga.html)
}

мет имема статус конституционной монархии в рамках Британского Содружества наций. Первым премьер-министром этой страны стам $\Lambda$ иеер Прогрессивной народной партии Аауда Ажавара, он же бым избран первым президентом в 1970 г., после того как Гамбия стала республикой. ВпослеАствии Ажавара побежаам на выборах еще шесть раз (в 1966, 1972, 1977, 1982, 1987 и 1992 гг.) и сохраним свою Аолжность Ао 1994 г. А. Ажавара принаАлежам кАоминирующей в стране роАопмеменной группе мандинго, получим образование в Авух европейскихуниверситетах (ГАазго и Аиверпукя, по специальности ветеринария), в стуАенческие годы бым членом мейбористской организации и приня х христианство ${ }^{3}$.

В октябре 1980 г. страну охватими массовые беспоряаки, в организации которых власти обвинями Аивию, ранее отказавшуюся преАоставить экономическую помощь Гамбии. По просьбе руководства Гамбии в страну вош ии военные сенегамьской армии и помогли подавить волнения, в ходе которых погибло Ао 900 человек. Спустя полгода - в конце июля 1981 г. в стране произошем военный переворот, широко поААержанный насемением. ГосуАарственную вмасть попыталась захватить мевая марксистская партия, ранее Аействовавшая в подполье - Революционная социалистическая партия Гамбии. Было объявмено о созАании Верховного Совета Революции в составе 3 военных и 9 гражАанских миц во главе с Кукои Самба Сантьянгом. На помощь Ажаваре пришел Сенегац. В странувошии сухопутные и возАушно-десантные сенегамьские войска, и в течение недеми мятеж бым подавлен. Во время подав ения антиправительственного восстания погибло более тысячи чемовек, спустя гоА 35 повстанцев были приговорены к смертной казни. Страх повторения мятежа и разрушенная экономика заставими президента Ажавару искать формы союза с Сенегалом.

ИАея объеАинения Сенегама и Гамбии в той ими иной форме всегАа «витала в возАухе». ПереА глазами мидеров Авух государств быми примеры такого объеАинения в историческом прошлом, в период соперничества в регионе Ан-

\footnotetext{
${ }^{3}$ Кто есть кто в мировой политике. М., 1990. С. 24.
} 
глиии Франции. Сенегамбия — королевская комония Британии - была создана в 1758 г., когАа англичанам уАалось вытеснить французов из устья реки Сенегам ${ }^{1}$. Колония просуществовала Ао 1783 г. и распалась после того, как Франция сумела вернуть свои прежние владения в Сен$\Lambda$ й $^{2}$. В 1860 - 1870 гг. Аве метрополии начали обсужАать коммерческий план объеАинения региона, в котором французы преАлагали обменять на Гамбию Аругое свое западно-африканское владение, но обмен так и не был завершен ${ }^{3}$. В 1960 гг. первыйпрезидент Сенегала $\Lambda$. Сенгор также вынашивам идею объединения с Гамбией идаже консультировалсяпо этомувопросу смежАународными организациями.

В феврале 1982 г. правительства Сенегала и Гамбии подписали Соглашение о создании Конфедерации Сенегамбия. Помимо сотруАничества в вопросах обороны и безопасности Конфедерация изначально предусматривала созАание еАиной экономической и финансовой системы, коорАинацию внешнеполитических акций и транспортной политики. Президентом Конфедерации согласно подписанному Аокументу являлся милер Сенегала, руководителю Гамбии отводилась роль его заместите$\Lambda я$. Вопрос о руководстве КонфеАерацией стал поводом аля ее роспуска в 1989 г. Истинными причинами несложившегося союза Авух сосеАних стран стали: неэффективность созАанных управленческих структур Конфедерации, намеренная задержка гамбийской стороной реализации ряда торговых и экономических соглашений (особенно таможенного союза), негласное поощрение руководством Гамбии незаконной торговии через границу.

В начале 1988 г. в Гамбии была преАотвращена очередная попытка государственного переворота. За участие в подготовке заговора были осуждены, в том числе граждане Сенега$\Lambda$ а, участники повстанческого Авижения в Ка-

\footnotetext{
${ }^{1}$ Richmond E. B. Senegambia and the Confederation: History, Expectations, and Disillusions // Journal of Third World Studies. 1993. (10.2). P. 177.

${ }^{2}$ Ibid. P. 182.

${ }^{3}$ Hughes A., Lewis J. Beyond Francophonie?: The Senegambia Confederation in Retrospect // State and Society in Francophone Africa since Independence. Ed. A. Kirk-Greene and D. Bach. Oxford. England: St. Martin's Press, 1995. P. 239.
}

замансе. Кроме того, в ходе слеАствия вспиыла информация о возможной причастности к организации переворота Аилера сенегальской оппозиции и будущего президента Сенегама - Абдумая ВаАа (такие показания Аам оАин из свидетемей).Это обстоятельство, по всей вероятности, также способствовало охлаждению отношений межау Авумя странами ${ }^{4}$. РаспаА Сенегамбии происходил на фоне острого пограничного конфмикта Сенегала с Мавританией. Позиция руководства Гамбии в этом конфликте, не оказавшего очевиАной подАержки своему союзнику (Сенегалу), сталадополнительным фактором распада Конфедерации.

11 августа 1989 г. А. Ажавара в «умьтимативном» послании президенту Сенегала АбАу Аиуфу выступим за сменяемость президента Сенегамбии и потребовац уступить ему этот пост с 1990 г. Гамбийский мидер также настаивал навыводе стерритории страны сенегальского воинского контингента, который находился там со времен переворота 1981 г. По мнению Аакарской газеты «Sud», A. Ажавару «вAoxновимо» на этот шаг подписание Аоговора об обороне с Нигерией. Подобное Аавление на фоне сложной внешнеполитической ситуации (обострения отношений Сенегала с Мавританией и Гвинеей-Бисау) бымо воспринято руководством Сенегана как «провокация» 5 . 24 августа 1989 г. президент А. Аиуф объявим о «замораживании» Аоговора о Сенегамбии, что фактически означало роспуск Конфедерации. Выступив с телевизионным обращением к нации, глава Сенегала заявиц, что не видит перспектив на пути интеграции Авух стран в условиях, когАа «институты конфедерации работают вхолостую». Президент Аиуф объявим также о выводе из Гамбии сенегальских воинских частей, входящих в состав конфедеральных вооруженных сим и сим безопасности ${ }^{6}$. В течение месяца с территории Гамбии бым выведен весь сенегальский контингент

\footnotetext{
${ }^{4}$ Гамбия. Приговор заговорщикам / / ИНФО-ТАСС. 1988. 27 июня. (http://www.info.itar-tass.com)

${ }^{5}$ Послание президента Гамбии // ИНФО-ТАСС. 1989. 13 августа. (http://www.info.itar-tass.com)

${ }^{6}$ Президент Сенегала призвал заморозить договор о Сенегамбии // ИНФО-ТАСС. 1989. 25 августа. (http://www. info.itar-tass.com)
} 
численностью 1300 человек, на значительную часть которого (жандармские подразделения) ранее была возможена задача обеспечения мичной безопасности А. Ажавары ${ }^{1}$. В последующие годы правления президента Ажавары отношения межАу Сенегамом и Гамбией оставамись Аостаточно напряженными. Во время обострения ситуации в Казамансе в 1990 г. некоторые официамьные мица в Сенегале подозревали, что Гамбия предоставмяет партизанам убежище на своей территории. Подозрения были связаны с массовым исходом беженцев Казаманса на территорию Гамбии. По Аанным правозащитных организаций, на территорию Гамбии и Гвинеи-Бисау от боевых Аействий в 1990 году бежамо более 2 тыс. чемовек ${ }^{2}$.

Несмотря на охмаждение отношений обе сосеАние страны - и Сенегал, и Гамбия быми заинтересованы в тесном сотрудничестве и периоАически Аелами попытки «растопить $\Lambda$ еА». К объеАинению в той иной форме стороны подталкивали общие экономические проблемы (перемещение через границу товаров и туристов, необходимость согласования взаимовыгодных таможенных тарифов и т.А.) и вопросы безопасности. Аля Сенегама Гамбия оставацась ключевым партнером (после Гвинеи-Бисау) в вопросе урегумирования проблемы Казаманса. В конце 1990 г. Банжул при содействии французского посла Андре Аевина и по просьбе Аакара организует совещания межАу размичными фракциями ААСК, направменные на их объеАинение и провеАение мирных переговоров. Итогом встреч и Аипломатическихусилий руководства Гамбии стало преодоление разногласии в политическом крыле ААСК и поАписание мирного Аоговора 1991 г. $^{3}$

ПосреАническая миссия Гамбии в казамансском вопросе ослабима напряженность в отношениях Авух стран после распада Конфелерации Сенегамбия. 25 мая 1991 г. в гамбийской столице Банжуле министры иностран-

\footnotetext{
${ }^{1}$ Об отношениях межАу Сенегамом и Гамбией / / ИНФОТАСС. 1989. 18 сентября. (http://www.info.itar-tass.com)

2 Повстанческое Авижение в Сенегаме // ИНФО-ТАСС. 1990. 25 Аекабря. (http://www.info.itar-tass.com)

${ }^{3}$ Foucher V. Pas d'Alternance en Casamance? // Politique Africaine. 2003. N 3 (91). P. 108.
}

ных Аел Сенегала и Гамбии подписали договор о Аружбе и сотруАничестве, призванный поставить отношения Авух стран «на путь мира, безопасности истабимьности». Выступая после церемонии поАписания Аоговора, глава МИА Сенегама Ажибо Ка особо отметим необходимость развитияэкономической интеграциии системы ком ективной безопасности в регионе. Новый Аоговор охватывам 13 областей сотруАничества и предусматривац, в частности, «свободное передвижение $ю$ юй и... имущества... транспортных среАств, развитие торгового обмена, сотрУАничество в суАебном Аелопроизводстве, в сфере обороны и безопасности $\gg$. В рамках Аоговора были заявлены ежегодные встречи глав Авух государств и созАана смешанная комиссия по сотрУАНичеству ${ }^{4}$.

\section{ВОЕННЫЙ ПЕРЕВОРОТ В ГАМБИИ. ПРИХОА ЯЙЯ АЖАММЕ}

В июле 1994 г. Ажавара бым свергнут военной хунтой в резумьтате бескровного переворота. Во главе путчистов стоям молодой мейтенант Яйя Ажамме. Захватившая власть хунта млаАших офицеров приостановима Аействие Конституции, отстранима от вцасти все правительство и старших офицеров, заключив

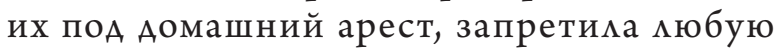
политическую Аеятемьность в стране и сформировала Временный Управмяющий Совет Boоружённых сим (Armed Forces Provisional Ruling Council). Гамбия наАомго попаАает в политическую и экономическую изоляцию. Основные поставщики межАунароАной помощи - США и Европейский Союз - приостанав ииват поставки, настаивая на возвращении в страну гражданского режима правления. Через ава года Я. Ажамме увольняется из Вооруженных сил, провоАит референаум по новой Конституции, а в сентябре 1996 г.президентские выборы, на которых побеждает с 56\% голосов. Спустя гоА, на парламентских выборах победу также одерживает партия президента Ажамме. По новой Конституции вся исполнитемьная власть сосредоточена в руках президента Гамбии, который явмяется оАновременно гмавой государства, прави-

\footnotetext{
${ }^{4}$ Емельянов В. Заключен договор о дружбе и сотрудничестве с Гамбией // ИНФО-ТАСС. 1991. 31 мая.
} 
темьства иглавнокомандующим вооружённых сим страны ${ }^{1}$.

После военного переворота 1994 года руководство Сенегала определенное время занимало выжидатемьную позицию с тем, чтобы выяснить намерения новых гамбийских властей в отношении конфмикта в Казамансе. Настороженность Сенегама объясня ась не только силовым способом захвата власти Я. Ажамме, но и его происхожАением из роАоплеменной группы Аиола. ХоАими устойчивые слухи о его тайных симпатиях к повстанцам ААСК и том, что они поААержаци его на презиАентских выборах в 1996 г. Аействитемьно, многие СМИ писали о том, что Аиома из Казаманса, имевшие Авойное гражАанство, во время выборов переходими границу, чтобы проголосовать за своего соп еменника Я. Ажамме, но никаких Аоказательств, что голосовавшие быми партизанами ААСК, приведено не было. Равно как и информация о связях Я. Ажамме сповстанцами всегАа остава ась на уровне слухов. Напротив, на официальном уровне президент Гамбии неоднократно выступам посреАником в урегулировании конфмикта и веАении мирных переговоров междуправитемьством Сенегама и сторонниками независимости Казаманса.

Официамьные отношения между Аакаром и Банжулом после переворота и смены вмасти в Гамбии были установлены в 1996 г. После избрания Ажамме президентом Абду Аиуф нанес официамьный визит в Банжул. По свидетемьствугамбийского посла в Сенегале Саер Ба, который участвовац в организации встречи, визит А. Аиуфа бым «как глоток свежего воздуха, он успокоим в известной степени и нароА Гамбии, и ее в $а$ асти $>^{2}$. В ходе встречи президентам УАамось Урегулировать ряА экономических вопросов: возобновимась транзитная торговля, было восстановмено и облегчено автомобимьное передвижение через границу, согласован тариф за переправу через р. Гамбия.

В конце 1997 г. наступление сенегамьской армии в Казамансе заставимо тысячи беженцев

\footnotetext{
${ }^{1}$ The Gambia. History / / Encyclopedia of Nations. (http:// www.nationsencyclopedia.com/Africa/The-GambiaHISTORY.html)

${ }^{2}$ Le Nouvel Horizon. Dakar, 1997, N 15. 17 Juillet.
}

и значительную часть партизан ААСК устремиться на север - через границу с Гамбией, что Аобавило нестабимьности РГ и поАтолкнуто ее новое руководство к переговорам с $\mathrm{Ce}$ негалом и участию в стабимизации ситуации. В 1998 г. Я.Ажамме в свою очередь посетим Аакар, гАе состоямись переговоры на высшем уровне, посвященные урегулированию конфиикта в Гвинее-Бисау. ПреАставитемь Гамбии принял активное участие в мирных переговорах во время «войны 7 июня» в Гвинее-Бисау, в которой сенегамьские войска участвовами на стороне президента Ж. Виейры. ОАнако, тогАа Аипломатические усимия гамбийской стороны не увенчамись успехом, натолкнувшись на противодействие руководства Сенегала, заинтересованного в продолжении военных Аействий на территории Бисау с цемью миквиАации тыловых баз сепаратистов ААСК (см. ГА. 6). В февраме 1999 г. Гамбия официамьно преАможила Сенегалу свое посреАничество в урегумировании конфмикта в южно-сенегацьской провинции Казаманс. Это преАложение бымо передано в ходе состоявшейся в Аакаре встречи межАу президентом Сенегама Абау Аиуфом и назначенным на пост главы МИА Гамбии Мамаду Седате Йопом. На последующей за переговорами пресс-конференции преАставитель Банжула заявиц, что его страна не виАит возможностей Аля поступатемьного развития запаАноафриканского региона без Аостижения в нем стабимьности. «Если оставить тлеть эту историю с Казамансом, она окажет негативное вмияние на экономическое развитие стран региона и нанесет ущерб сенегамо-гамбийскому сотрудничеству ,- заявим он $^{3}$.

\section{ГАМБИЯ В 2000-Е ГОАЫ. ПЕРСПЕКТИВЫ СЕНЕГА АО- ГАМБИЙСКИХ ОТНОШЕНИЙ}

В 2000 гг., в период правления в Сенегане президента ВаАа, отношения Авух стран комебались межАу напряженностью и сотруАничеством, больше скмоняясь К послеАнему. Как отмечает исследователь В. Фуше, позиция Я. Ажамме в южно-сенегамьском конфмикте никогАа не своАимась к его «этнической

\footnotetext{
${ }^{3}$ Le Nouvel Horizon. Dakar, 1999. 8 Février.
} 
солидарности с Аиола Казаманса». ОАнако «хрупкость и нестабимьность» гамбийского

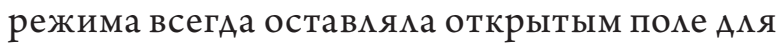
Аеятемьности партизан ААСК ${ }^{1}$. Ромь территории Гамбии в транзите инАийской конопли, который контромировами мидеры Северного фронта ААСК, и контрабанде оружия Аля повстанцев труано переоценить. ОАнако утвержАать, что к незаконному обороту наркотиков и оружия имело отношение высшее руковоство Гамбии, нет никаких оснований. Напротив, очевидна прямая заинтересованность гамбийского мидера в умиротворении ситуации в Казамансе. Последствия сенеганьских военных операций на территории, примегающей к южной границе РГ, негативно отражамись на обстановке внутри самой Гамбии. Присутствие тысяч беженцев из Казаманса на гамбийской территории созАавало напряженность межАу ними и местными житемями, что в мае 2003 г., например, вылимось в острый конфиикт в родной Аеревне Ажамме Канимаи. В итоге на территорию Сенегама быми репатриированы несколько тысяч человек ${ }^{2}$. Еще ранее - в мае-июне 2001 года — вмасти Гамбии быми вынуждены закрыть магерь беженцев в Сайфо Аранколи, расположенный прямо на границе с Сенегалом, и переселить часть его жителей (окомо 1500 человек) в Аругое место, ближе к побережью, а часть (поряАка 2000 беженцев) - отправить в Сенега ${ }^{3}$.

После крушения в 2002 г. у берегов Гамбии сенегамьского парома «Joola», который направлялся из Зигиншора в Аакар, по Казамансу прокатилась волна массовыхпротестов против центрального правитецьства. РоАственникипочти 2 тысяч погибших, не получившие от правите ьства Аолжной финансовой компенсации, обвиняли власти в халатности и пренебрежении к нужАам житемей южной области. Паром 1990 г. постройки вышел в море сразу после Аесятимесячного ремонта. Число пассажиров на борту судна во время его крушения превы-

\footnotetext{
${ }^{1}$ Foucher V. Pas d'Alternance en Casamance? // Politique Africaine. 2003. N 3 (91). P. 109.

${ }^{2}$ Ibidem.

${ }^{3}$ IRIN. 23 июня 2001, 7 июля 2001 (http://www.irinnews. org/country/gm/gambia)
}

шало Аопустимое почти в Ава раза, что, по всей вероятности, и послужимо причиной затопления ${ }^{4}$. ТрагеАия в Казамансе остро поставима проблему транспортного сообщения межАу Аакаром и Казамансом. В этой ситуации Яйя Ажамме в апреле 2003 г. выступает с эффектной и своевременной инициативой по строитемьству моста через реку Гамбия (проект, затянувшийся на годы и незавершенный Ао сих пор), реализация которой быма призвана снять проблему и связать столицу Сенегала с южной провинцией напрямую - через территорию Гамбии ${ }^{5}$.

Помитическое развитие Республики Гамбия в послеАние 20 мет было связано с посто-

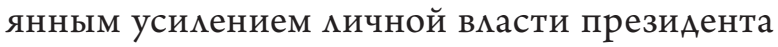
Ажамме, что фактически привело к установмению в стране Аиктатуры. При формахьном сохранении Аемократических и гражданских структур власти (страна оставацась президентской респубцикой) милер Гамбии в реацьности практиковац трайбамизм и кмановость, назначая на высокие посты преАставителей «своей» группы (Аиола), часто - ближайших родственников. БуАучи истовым мусумьманином, в Аекабре 2000 г. Я. Ажамме заявим о намерении ввестишариатв правовую системугосударства ${ }^{6}$. Во второй половине 2000-х гг. режим Ажамме ускоренными темпами Авигался в сторону помной маргинамизации и изомяции от межАународного сообщества, главным образом от стран Запада. Постепенно в Гамбии быми свернуты все Аемократические институты, объявлена вне закона Аеятельность мюбыхправозащитных организаций. В 2008 г. узаконено

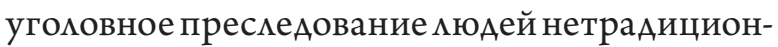
ной сексуа ьной ориентации, которым грозило Ао 14 лет мишения свободы. «Гамбия - страна верующих. Такие греховные и аморамьные практики, как гомосексуамизм, неАопустимы »,заявим президент Ажамме, предоставив всем гомосексуалистам 24 часа на то, чтобы выехать

\footnotetext{
${ }^{4}$ Senegal: «Le Joola» compensation delayed by dispute // IRIN. 4July 2003. (http://www.irinnews.org/report/44756/ senegal-le-joola-compensation-delayed-by-dispute)

${ }^{5}$ Foucher V. Op. cit. P. 109.

${ }^{6}$ Современная Африка: метаморфозы политической вмасти. М., 2009. С. 318.
} 
из страны1 ${ }^{1}$ Гамбийский Аиктатор всегАа отмичался большой эксцентричностью. К примеру, в аАрес правозащитников Я. Ажамме публично в 2009 г. озвучим угрозы физической расправы: «Если вы связаны с какой-нибудь правозащитной группой, будьте уверены в том, что вам не гарантирована безопасность. Мы готовы убивать вредителей... Если вы думаете, что можете сотрудничать с так называемыми защитниками прав человека и вам это сойдет с рук, значит, вы живете в своем собственном придуманном мире. Я вас убью, так что ничего из этого не выйдет»².

В конце 2000-х гг. преследование инакомыслящих достигает запредельного размаха. Порядка 70\% гамбийскихинтеммектуалов за послеАние годы покинули страну - ими явмяясь помитическими изгнанниками, ими из опасения попасть поА репрессии. В начале 2009 г. Ажамме обвиняет «колАунов» в смерти своей родственницы и объявмяет в стране реальную «охоту на ведьм». Преследования приобретают форму настоящей параноиАальной фобии. По Аанным международной правозащитной организации Amnesty International, жертвами кампании против колдунов стали около тысячи человек, в основном преклонного возраста. Аюдей похищали и содержали в тайных центрах, заставляя пить гамлюциногенные снадобья. По словам очевидцев, в облавах принимами участие полицейские, военные, сотрудники развеАки и мичной охраны президента, а также некие «знахари», приближенные к президенту. При этом Я. Ажамме утвержАац, что сам обладает сверхъестественными способностями ${ }^{3}$ В В ноябре 2010 г. мидер Гамбии выступим с новой эксцентричной инициативой, заявив,

\footnotetext{
${ }^{1}$ Гамбия вышла из Британского Содружества Наций, милер республики обвиняет бывшую метрополию в «неоколониализме» // Русская пианета. 3 октября 2013.

2 Президент Гамбии пообещац поубивать всех правозащитников // Коммерсант.Ru. 5 октября 2009. (http:// www.kommersant.ru/doc/1243495)

3 The Gambia: Hundreds accused of «witchcraft» and poisoned in government campaign // Amnesty International. 18 March 2009. (http://www.amnesty.org/ en/for-media/press-releases/gambia-hundreds-accused$\%$ E2\% 80\%9Cwitchcraft $\%$ E2\% 80\%9D-and-poisonedgovernment-campaign-20)
}

что хочет стать королем в своей стране. Обеспечить грядущей коронации поАдержку среАи населения было поручено племенным иилерам Гамбии. В настоящее время официальный титул главы государства звучит как Его превосходительство президент шейх профессор аль-хаАжи Аоктор Яйя Ажамме ${ }^{4}$. Это напоминает громкие титулы самых одиозных африканских Аиктаторов - ИАи Амина, Масиаса Нгемы Бийого, Мобуту Сесе Секо. В сущности, реализация инициативы гамбийского мидера не внесла бы серьезных изменений в политическую жизнь страны, поскольку Аиктатор и так контролирует государство практически еАинолично ему подчиняются оппозиция, пресса и Ауховенство. В октябре 2013 г., обвинив западные страны в неоколониализме, мидер Гамбии объявим о выходе страны из Содружества наций а в марте 2014 г.— об отказе от английского языка как государственного 6 . На каком языке теперь будут работать официальные службы и вестись Аелопроизводство пока неясно, поскольку в Гамбии нет такого африканского языка, которым владела бы большая часть населения.

В таких условиях руководству Сенегала страны ориентированной на тесное сотруАничество с Евросоюзом и США — подАерживать Ааже виАимость гармоничных отношений с Гамбией крайне сложно. ОАнако наличие общих экономических вопросов, зависимость от Гамбии в транспортной сфере и, наконец, тмеющая проблема Казаманса заставмяют миАеров Сенегала Аелать периодические «реверансы» перед безумствующим Аиктатором, подписываясь в добрых намерениях. Впрочем, получая периодические ответные «книксены». Так, во время своего визита в Гамбию в качестве «почетного гостя» в феврале 2013 г. по случаю

\footnotetext{
${ }^{4}$ Выпей за зАоровье нации. Президент Гамбии изъявик жемание стать коромем / / Lenta.ru. 10 ноября 2010. (http:/ / lenta.ru/articles/2010/11/10/yahya/)

${ }_{5}^{5}$ Гамбия вышиа из Британского Содружества Наций, мидер республики обвиняет бывшую метрополию в «неоколониализме» // Русская пианета. 3 октября 2013.

(http://rusplt.ru/world/strana-bez-geev-koldunovpravozaschitnikov-i-vliyaniya-zapada.html)

${ }^{6}$ ФАаг, Аеньги, язык // Коммерсант.Ru. 17 марта 2014. (http://www.kommersant.ru/doc/2416142)
} 
празднования Аня Независимости РГ презиАент Маки Салмь объявим «колмеге» о желании укрепить Аавние отношения межАу Авумя странами путем консолидации народов Сенегамбии и ихэкономических интересов. «Аружба и братство между народами Сенегала и Гамбии будут усимены через согласие межАу Авумя народами и правительствами, укрепление африканского еАинства»,- сказал президент Сенегама ${ }^{1}$. Прекрасной имлюстрацией этой консолидации, по мнению М. Салмя, Аолжно стать строительство моста через реку Гамбия, который «свяжет народы и экономики» Авух стран (речь шла об инициативе 12-летней Аавности, так и не реацизованной до сих пор) ${ }^{2}$.
Участник оАного из крупнейших АиссиАентских Авижений Гамбии - Гамбийского Консультативного Совета, журналист и писатель Мэтью Ажемлоу, высланный из Гамбии в США, считает, что Аиктаторскому военнизированному режиму в Гамбии Аолжен скоро прийти конец. Об этом свидетельствует то, что политика Яйя Ажамме в своем антидемократизме, трайбализме, презрении к нормам межАународного права Аошма Ао высшей точки и утратика всякую поААержку у населения страны ${ }^{3}$. Ао тех пор, пока политическая власть в Гамбии не изменится, надежАа Сенегала урегулировать конфмикт в Казамансе будет оставаться призрачной, считает М. Ажелмоу.

\section{БИБАИОГРАФИЯ}

1. The World Factbook-Senegal // Central Intelligence Agency (https://www.cia.gov/library/ publications/the-world-factbook/geos/sg.html)

2. Кто есть кто в мировой политике. М., 1990.

3. Richmond E.B. Senegambia and the Confederation: History, Expectations, and Disillusions // Journal of Third World Studies. 1993. (10.2). P. 177.

4. Hughes A., Lewis J. Beyond Francophonie?: The Senegambia Confederation in Retrospect // State and Society in Francophone Africa since Independence. Ed. A. Kirk-Greene and D. Bach. Oxford. England: St. Martin's Press, 1995.

5. Гамбия. Приговор заговорщикам // ИНФО-ТАСС. 1988.27июня. http://www.info.itar-tass.com

6. Послание президента Гамбии // ИНФО-ТАСС. 1989. 13 августа. (http://www.info.itar-tass.com)

7. Президент Сенегала призвац заморозить договор о Сенегамбии // ИНФО-ТАСС. 1989. 25 августа. (http://www.info.itar-tass.com)

8. Об отношенияхмежАу Сенегалом и Гамбией // ИНФО-ТАСС. 1989. 18 сентября. (http://www. info.itar-tass.com)

9. Повстанческое Авижение в Сенегаме // ИНФО-ТАСС. 1990.25 Аекабря. (http://www.info.itartass.com)

10. Foucher V. Pas d’Alternance en Casamance? // Politique Africaine. 2003. N 3 (91). P. 108.

11. Емельянов В.Заключен Аоговор о Аружбе и сотруАничестве с Гамбией // ИНФО-ТАСС. 1991. 31 мая.

12. The Gambia. History // Encyclopedia of Nations. (http://www.nationsencyclopedia.com/Africa/ The-Gambia-HISTORY.html)

13. Le Nouvel Horizon. Dakar, 1997, N 15. 17 Juillet.

14. Le Nouvel Horizon. Dakar, 1999. 8 Février.

15. Foucher V. Pas d'Alternance en Casamance? // Politique Africaine. 2003. N 3 (91). P. 109.

16. IRIN. 23 июня 2001, 7 июля 2001 (http://www.irinnews.org/country/gm/gambia)

\footnotetext{
${ }^{1}$ Macky Sall à Banjul: «Nous allons consolider la Sénégambie des peuples et la Sénégambie économique» // Senego. 18 февраля 2013 (http://senego.net/senegal/2013/02/18/ macky-sall-homologue-gambien-allons-consolidersenegambie-peuples-senegambie-economique_77699.html) ${ }^{2}$ Ibidem.
}

\begin{abstract}
${ }^{3}$ Jallow M. K. Senegambia: Gambia's permanent state of crisis and Senegal's impossible peace // Senegambia News. 16 February 2014. (http://www.senegambianews. com/1333/65871/a/senegambia-gambias-permanent-stateof-crisis-and-senegals-impossible-peace)
\end{abstract}


17. Манойло А.В. «Финиковые революции»: стихия или управляемый хаос?//МежАунароАная жизнь. - 2011.-№5. - С. 63-78.

18. Senegal: «Le Joola» compensation delayed by dispute // IRIN. 4 July 2003. (http://www.irinnews. org/report/44756/senegal-le-joola-compensation-delayed-by-dispute)

19. Современная Африка: метаморфозы политической власти. М., 2009.

20. Гамбия вышла из Британского Содружества Наций, мидер республики обвиняет бывшую метрополию в «неоколониализме» // Русская планета. 3 октября 2013.

21. Президент Гамбии пообеща поубивать всех правозащитников // Коммерсант.Ru. 5 октября 2009. (http://www.kommersant.ru/doc/1243495)

22. The Gambia: Hundreds accused of "witchcraft" and poisoned in government campaign // Amnesty International. 18 March 2009. (http://www.amnesty.org/en/for-media/press-releases/ gambia-hundreds-accused-\%E2\% 80\%9Cwitchcraft $\%$ E2\%80\%9D-and-poisoned-governmentcampaign-20)

23. Выпей за зАоровье нации. Президент Гамбии изъявим желание стать коромем // Lenta.ru. 10 ноября 2010. (http://lenta.ru/articles/2010/11/10/yahya/)

24. ФАаг, Аеньги, язык // Коммерсант.Ru. 17 марта 2014. (http://www.kommersant.ru/ $\operatorname{doc} / 2416142)$

25. Macky Sall à Banjul: «Nous allons consolider la Sénégambie des peuples et la Sénégambie économique» // Senego. 18 февраля 2013 (http://senego.net/senegal/2013/02/18/macky-sallhomologue-gambien-allons-consolider-senegambie-peuples-senegambie-economique_77699. html)

26. Jallow M.K. Senegambia: Gambia's permanent state of crisis and Senegal's impossible peace // Senegambia News. 16 February 2014. (http://www.senegambianews.com/1333/65871/a/ senegambia-gambias-permanent-state-of-crisis-and-senegals-impossible-peace)

27. Валиул ин И.И. Эволюция понятия «информационная война» в политической науке // МежАународные отношения. - 2014. - 1. - С. 68 - 74.DOI: 10.7256/2305-560X.2014.1.10064.

28. Карпович О.Г. МежАународные организации и их роль в предупрежАении, урегулировании и разрешении этнополитических конфмиктов // Национальная безопасность / nota bene. - 2014. - 3. - C. 398 - 405. DOI: 10.7256/2073-8560.2014.3.11786.

29. Манойло А.В. О противодействии цветным революциям // МежАународные отношения. 2014. - 3. - C. 332 - 363. DOI: 10.7256/2305-560X.2014.3.12060.

30. О.Г. Карпович Формат управления межАународными конфмиктами США и ЕС в современных миротворческих операциях // МежАународные отношения. — 2012. — 1. — С. 88 — 99.

\section{REFERENCES (TRANSLITERATED)}

1. The World Factbook-Senegal // Central Intelligence Agency (https://www.cia.gov/library/ publications/the-world-factbook/geos/sg.html)

2. Kto est' kto v mirovoi politike. M., 1990.

3. Richmond E.B. Senegambia and the Confederation: History, Expectations, and Disillusions // Journal of Third World Studies. 1993. (10.2). P. 177.

4. Hughes A., Lewis J. Beyond Francophonie?: The Senegambia Confederation in Retrospect // State and Society in Francophone Africa since Independence. Ed. A. Kirk-Greene and D. Bach. Oxford. England: St. Martin's Press, 1995.

5. Gambiya. Prigovor zagovorshchikam // INFO-TASS. 1988. 27 iyunya. http://www.info.itar-tass. com

6. Poslanie prezidenta Gambii // INFO-TASS. 1989. 13 avgusta. (http://www.info.itar-tass.com)

7. Prezident Senegala prizval zamorozit' dogovor o Senegambii // INFO-TASS. 1989. 25 avgusta. (http://www.info.itar-tass.com)

8. Ob otnosheniyakh mezhdu Senegalom i Gambiei // INFO-TASS. 1989. 18 sentyabrya. (http:// www.info.itar-tass.com) 
9. Povstancheskoe dvizhenie v Senegale // INFO-TASS. 1990. 25 dekabrya. (http://www.info.itartass.com)

10. Foucher V. Pas d'Alternance en Casamance? // Politique Africaine. 2003. N 3 (91). P. 108.

11. Emel'yanov V. Zaklyuchen dogovor o druzhbe i sotrudnichestve s Gambiei // INFO-TASS. 1991. 31 maya.

12. The Gambia. History // Encyclopedia of Nations. (http://www.nationsencyclopedia.com/Africa/ The-Gambia-HISTORY.html)

13. Le Nouvel Horizon. Dakar, 1997, N 15. 17 Juillet.

14. Le Nouvel Horizon. Dakar, 1999. 8 Février.

15. Foucher V. Pas d'Alternance en Casamance? // Politique Africaine. 2003. N 3 (91). P. 109.

16. IRIN. 23 iyunya 2001, 7 iyulya 2001 (http://www.irinnews.org/country/gm/gambia)

17. Manoilo A.V. «Finikovye revolyutsii»: stikhiya ili upravlyaemyi khaos?//Mezhdunarodnaya zhizn'. - 2011.-№5. - S. 63-78.

18. Senegal: «Le Joola» compensation delayed by dispute // IRIN.4 July 2003. (http://www.irinnews. org/report/44756/senegal-le-joola-compensation-delayed-by-dispute)

19. Sovremennaya Afrika: metamorfozy politicheskoi vlasti. M., 2009.

20. Gambiya vyshla iz Britanskogo Sodruzhestva Natsii, lider respubliki obvinyaet byvshuyu metropoliyu v «neokolonializme» // Russkaya planeta. 3 oktyabrya 2013.

21. Prezident Gambii poobeshchal poubivat' vsekh pravozashchitnikov // Kommersant.Ru. 5 oktyabrya 2009. (http://www.kommersant.ru/doc/1243495)

22. The Gambia: Hundreds accused of "witchcraft" and poisoned in government campaign // Amnesty International. 18 March 2009. (http://www.amnesty.org/en/for-media/press-releases/ gambia-hundreds-accused-\%E2\%80\%9Cwitchcraft\%E2\%80\%9D-and-poisoned-governmentcampaign-20)

23. Vypei za zdorov'e natsii. Prezident Gambii iz"yavil zhelanie stat' korolem // Lenta.ru. 10 noyabrya 2010. (http://lenta.ru/articles/2010/11/10/yahya/)

24. Flag, den'gi, yazyk // Kommersant.Ru. 17 marta 2014. (http://www.kommersant.ru/doc/2416142)

25. Macky Sall à Banjul: «Nous allons consolider la Sénégambie des peuples et la Sénégambie économique» // Senego. 18 fevralya 2013 (http://senego.net/senegal/2013/02/18/macky-sallhomologue-gambien-allons-consolider-senegambie-peuples-senegambie-economique_77699. html)

26. Jallow M.K. Senegambia: Gambia's permanent state of crisis and Senegal's impossible peace // Senegambia News. 16 February 2014. (http://www.senegambianews.com/1333/65871/a/ senegambia-gambias-permanent-state-of-crisis-and-senegals-impossible-peace)

27. Valiullin I.I. Evolyutsiya ponyatiya «informatsionnaya voina» v politicheskoi nauke // Mezhdunarodnye otnosheniya. - 2014. - 1. - C. 68 - 74. DOI: 10.7256/2305560X.2014.1.10064.

28. Karpovich O.G. Mezhdunarodnye organizatsii i ikh rol' v preduprezhdenii, uregulirovanii i razreshenii etnopoliticheskikh konfliktov // Natsional'naya bezopasnost' / nota bene. — 2014 - _ 3. - C. 398 - 405. DOI: 10.7256/2073-8560.2014.3.11786.

29. Manoilo A.V. O protivodeistvii tsvetnym revolyutsiyam // Mezhdunarodnye otnosheniya. 2014. - 3. - C. 332 - 363. DOI: 10.7256/2305-560X.2014.3.12060.

30. O. G. Karpovich Format upravleniya mezhdunarodnymi konfliktami SShA i ES v sovremennykh mirotvorcheskikh operatsiyakh // Mezhdunarodnye otnosheniya. - 2012. - 1. - C. 88 - 99. 